\title{
GLUTAMATE TRANSMISSION AND TOXICITY IN ALZHEIMER'S DISEASE
}

J. TIMOTHY GREENAMYRE, WILLIAM F. MARAGOS, ROGER L. ALBIN, JOHN B. PENNEY and ANNE B. YOUNG

Department of Neurology and Neurosclence Program, University of Michigan Medical Center, Ann Arbor, MI, USA

(Final form, September 1987)

\section{Contents}

$\begin{array}{lr}\text { Abstract } & 421 \\ \text { 1. Introduction } & 421 \\ \text { 2. Pathogenesis } & 422 \\ \text { 3. Clinical Manifestations } & 425 \\ \text { 4. In vivo Imaging } & 426 \\ \text { 5. Therapy } & 427 \\ \text { 6. Conclusions } & 427 \\ \text { Acknowledgements } & 427 \\ \text { References } & 428\end{array}$

\begin{abstract}
Greenamyre, J. Timothy, William F. Maragos, Roger L. Albin, John B. Penney and Anne B. Young: Glutamate transmission and toxicity in Alzheimer's disease. Progr. Neuro-Psychopharmacol.\& B1ol. Psychiat. 1988, 12:421-430

1. Despite intensive research, the cause of Alzheimer's disease 1 s unknown.

2. Glutamate is the major excitatory transmitter of the cerebral cortex and hippocampus and it appears to have an important role in learning and memory. In addition to its transmitter function, glutamate is a neurotoxin which has been implicated in the pathogenesis of a variety of neurodegenerative disorders.

3. Glutamate toxicity may play a role in the pathogenesis of Alzheimer's disease.

4. Disruption of glutamatergic neurotransmission may account, in part, for the learning and memory deficits of Alzheimer's disease.

5. Labeling of the glutamate receptor complex may allow in vivo diagnosis by positron emission tomography.

6. Glutamate receptor ligands may provide a means of therapeutic intervention in Alzheimer's disease.

Keywords: Alzheimer's disease, excitotoxin, glutamate, N-methyl-D-aspartate, tetrahydroaminoacridine, quisqualate

Abbreviations: dementia of the Alzhelmer type (DAT), tetrahydroaminoacridine (THA), Nmethyl-D-aspartate (NMDA), phencyclidine (PCP), positron emission tomography (PET)
\end{abstract}

\section{Introduction}

Dementia of the Alzheimer type (DAT) is a common and debilitating disease that affects about one in $81 x$ persons over the age of sixty five (Khachaturian, 1985). It is characterized by progressive memory and learning deficits and signs of cortical 
disconnection. The etlotogy of DAT is unknown and the causes of its clinical manifestations are just beginning to be elucidated. Neurochemical studies of DAT have revealed decreases in cortical markers for a variety of neurotransmitters, (Wurtman et al., 1984). In particular, the cholinergic deficit in DAT has recelved considerable attention (Coyle et al., 1983). However, the relative importance of these neurotransmitter changes in the pathogenesis and symptomatology of DAT is unknown.

Glutamate is belleved to be the major excitatory transmitter of the cerbral cortex and hippocampus (Fagg and Foster, 1983). Its excitatory actions are mediated by at least 3 distinct receptor types named for N-methyl-D-aspartate (NMDA), quisqualate and kainate, the most specific agonists at each of the receptor types (Watkins and Evans, 1981). The distribution and pharmacology of these receptor types have been studied by binding techniques, including receptor autoradiography (Foster and Fagg, 1984). There is an excellent correspondence between the distribution of receptors and the terminal flelds of glutamatergic pathways (Greenamyre et a1., 1984; Greenamyre et al., 1985a; Halpain et al., 1984; Monaghan and Cotman, 1985).

The NMDA receptor is coupled to an Ion channel that 18 gated by magnesium in a voltage-dependent fashion (Nowak et al., 1984). Dissociative anesthetics, like ketamine and phencyclidine, are noncompetitive antagonists of the NMDA receptor which act at the Ion channel (Martin and Lodge, 1985). The distribution of dissociative anesthetic binding sites is highly correlated with that of MMDA receptors (Maragos et al., 1986).

In addition to its role as a neurotransmitter, glutamate is also a neurotoxin ("excitotoxin") which has been implicated in the pathogenesis of neuronal death in a varlety of neurodegenerative diseases (Greenamyre, 1986; Engelsen, 1986). Based on experimental evidence, we speculate in this article that (1) glutamate toxicity may play a role in the pathogenesis of DAT, (11) disruption of glutamatergic neurotransmission accounts for some of the clinical manifestations of DAT, (111) labeling of the glutamate receptor complex may allow $\underline{\text { In }}$ vivo diagnosis by means of positron emission tomography (PET), and (1v) glutamate receptor ligands may provide a means of therapeutic intervention in DAT.

\section{Pathogenes18}

The neurotoxic properties of glutamate and related compounds ("excitotoxins") have been recognized since 1957 (Lucas and. Newhouse, 1957). It Is now thought that glutamate toxiclty may play a role in the cell death associated with Huntington's disesse, olivopontocerebellar atrophy, hypoxia/1schemla, hypoglycemia and status epilepticus (Greenamyre, 1986; Enge1sen, 1986). The NMDA receptor, in particular, appears to mediate excitotoxic events and NMDA antagonists are protective in hypoxia/ischemia and Insulin-1nduced hypoglycemia. Noncompetitive antagonists acting at the fon channel are similarly protective.

Although there have been recent exciting insights into the genetics of DAT (Selkoe, 1987), the bastc pathogenetic mechanisms of the disease remain obscure. Several 1 ines 
of evidence suggest that glutamate excitotoxicity may contribute to the pathogenesis of DAT. If such a mechanism were at work in cortex and hippocampus in DAT, certain predictions concerning the course of the disease would follow loglcally (Table 1). First, because glutamate receptors mediate the toxic effects of glutamate, there should be selective damage to structures containing these receptors. With progression of the disease, and continued damage to these structures, there would ultimately be a loss of receptors. A second prediction of the excitotoxic hypothesis is that the distribution of pathology in DAT should correspond to the terminal fields of glutamatergic pathways in cortex and hippocampus. Third, it would be expected that application of excitotoxins would reproduce the neurochemical pathology of DAT. Fourth, it might be expected that excitotoxins would produce pathological stigmata similar to those seen in DAT.

With respect to the first prediction, we have shown a large decrease in glutamate receptors in cortex and hippocampus of DAT brains as compared to age- and post mortem delay-matched controls (Greenamyre et al., 1985b; Greenamyre et a1., 1987). G1utamate binding was normal in the caudate, putamen, claustrum and nucleus basalis of Meynert of DAT brains. In the cortex, we have shown that decreased binding was due to a $108 \mathrm{~s}$ of receptors and not to a change in their affinity (Greenamyre et al., 1985b). Although total glutamate binding was decreased, the most profound losses were found in MMDdisplaceable binding. In the inftial series of 6 DAT brains studied, NMDA-displaceable binding was decreased by about $60 \%$ in temporal cortex and by almost $90 \%$ in the stratum pyramidale of the CA1/CA2 region of the hippocampal formation. In a subsequent series of 9 DAT and 9 control brains, in which assays were performed and data were analyzed by observers blind to the diagnoses, 50-60\% 10s8es of hippocampal NMDA receptors were found (Debowey et al., 1987). Furthermore, as another measure of NMDA receptor function, we have shown that dissociative anesthetic binding sites, which presumably label the Ion channels associated with the NMDA receptor, are also decreased in DAT (Maragos et al., 1987). Similar findings in NMDA and dissoclative anesthetic binding sites have been reported by others (Geddes et al., 1986; Monaghan et al., 1987 ).

The shrunken dendritic arbor of cortical pyramidal celis in DAT (Mehraein et al., 1975) likely represents an anatomical correlate of this receptor loss and is possibly secondary to excitotoxicity. The earliest neuropathological evidence of toxic exposure to glutamate is dendritic swelling (0lney et al., 1979), consistent with the known dendritic localization of glutamate receptors (Greenamyre et al., 1984).

Table 1

Predictions of the Glutamate ("Bxcitotoxic") Hypothesis

1. Damage to structures contalning glutamate receptors - leading ultimately to a 1088 of glutamate receptors.

2. The distribution of pathology should correspond to the terminal fields of glutamate pathways.

3. Applications of excltotoxins should reproduce the neurochemical pathology of DAT.

4. Excitotoxins should produce neuropathological stigmata similar to those of DAT. 
There have been many unsuccessful attempts to correlate the distribution of pathology in DAT with specific transmitter systems. Notably, it has been shown that the distribution of cortical cholinergic Innervation does not correlate well with the pathology of DAT (Mesulam et al., 1986). In contrast, several laboratorles have argued that the distribution of senile plaques and neurofibrillary tangles, the hallmarks of pathology In DAT, correlates best with the terminal fields of cortical association pathways (Pearson et al., 1985; Rogers and Morrison, 1985). These pathways are believed to use glutamate as their transmitter (Fagg and Foster, 1983), consistent with the second prediction of the excitotoxic hypothesis. In fact, it has been suggested that the damage in DAT may propagate along association pathways (Pearson et al., 1985). The axons of corticocortical association pathways terminate primarily in superficlal and deep layers ( $V$ and VI) of other cortical regions (Lorente de No, 1934). Senile plaques In DAT are concentrated in these layers and are densest in zones of association fiber termination (Pearson et al., 1985; Rogers and Morrison, 1985). We have noted the greatest loss of NMDA receptors in these cortical layers (Greenamyre et al., $1985 \mathrm{~b}$ ).

Recent evidence suggests that glutamate neurotoxiclty can produce biochemical and anatomical changes similar to those seen in DAT. NMDA app1led to the cortical surface causes retrograde degeneration of cholinergic neurons in the nucleus basalis of Meynert in rats (Sofroniew and Pearson, 1985). This suggests that cortical excitotoxic events might be responsible for the subcortical atrophy seen in most DAT brains. Applications of excitotoxins to the hippocampus have also produced decreases in local levels of somatostatin simflar to those reported in DAT (McKinney et al., 1982).

The excitotoxic hypothesis also suggests that glutamate should be able to produce neuropathological changes simflar to those of DAT. DeBont and Crapper-McLachlan (1985) demonstrated the induction of pafred helical filaments simflar to those which make up neurofibrillary tangles, by incubation of cultured human neurons with glutamate. This remalns to be confirmed using immunohistochemistry with antibodies against DAT paired helical filaments. Hippocampal NMDA receptor loss, a possible index of excitotoxic damage, correlates with the density of neurofibrillary tangles (Debowey et al., 1987). Together, these data suggest that glutamate toxicity may contribute to the pathogenesis of DAT (Table 2).

Table 2

The Role of Glutamate in the Pathogenesis of DAT

- Glutamate is an "excitotoxin" and causes neuronal death.

- There is a loss of structures containing glutamate receptors in DAT.

- The pathology of DAT correlates with glutamatergic association pathways.

- Excitotoxins produce retrograde degeneration in the nucleus basalis.

- Neurochemical changes of DAT can be duplicated by excitotoxins.

- Glutamate can induce paired helical filaments in cultured human neurons. 
It is Important to note that glutamate toxicity need not be the primary event in the development of DAT. The primary defect in DAT might be any pathological process leading to an Impaired ability of neurons to maintain their normal membrane potential. At less negative membrane potentials, the voltage-dependent NMDA receptor fon channels would be more easily activated. This might lead to more prolonged NMDA receptor-mediated "burst firing" and the cell would be even more vulnerable to subsequent excitatory input and excitotoxicity. In this way, even though the primary defect in DAT might be unrelated to the glutamatergic system, considerable damage and the pattern of 1 ts spread $\mathrm{m} 1 \mathrm{ght}$ be due to excitotoxicity.

\section{Clinical Manifestations}

Clinically, DAT is characterized by signs of cortical disconnection, such as the agnosias and apraxias, and by progressive learning and memory deftcits. Because corticocortical and corticohippocampal pathways are believed to use glutamate as thelr transm1tter, the decreased number of glutamate receptors we have reported in DAT bratns would be expected to result in impaired synaptic communication in the cortex and hippocampus.

In addition to this postsynaptic defect in cortcal and hippocampal communication, there is likely to be a presynaptic component to the impaired glutamatergic transmission. It would be expected that during the progression of the disease, there would be a loss of the glutamatergic neurons which give rise to the association pathways, because these neurons themselves recelve converging glutamate 1nput. Consistent with this, classic morphometric studies have shown a marked, selective loss of large pyramidal cortical neurons In DAT (Terry et a1., 1981; Mann et a1., 1986). The degree of dementia is correlated with the degree of loss of these cells. These neurons have been shown in monkeys to be glutamatergic (Aldo Rustioni, personal communication), but confirmatory studies using glutamate Immunohistochemistry in human control and DAT brains must be performed.

There is, however, other evidence for loss of glutamate neurons in DAT. Recently, Hyman et a1 (1984) demonstrated a profound loss of cells in the subiculum which project to the hippocampal formation; this effectively isolates the the hippocampus from cortical input. Abundant evidence from animal studies suggests that this pathway is glutamatergic. More recently, Hyman et al (1986) reported that with loss of these cells In DAT, there is an $83 \%$ decrease in glutamate levels in the terminal fields of this projection. Interestingly, cognitive test scores correlate with CSF glutamate levels in DAT patients (Smith et al., 1985).

In summary, there is evidence of both pre- and postsynaptic disruption of the glutamaterglc association pathways. Such a disturbance might account, in part, for the clintcal impression of cortical disconnection and its behavioral correlates (Table 3 ).

How might be glutamate system be involved in the memory deficits of DAT? Several 
laboratories have shown that activation of the NMDA receptor is required for the development of most forms of long-term potentiation (LTP), a model for learning and memory, and NMDA receptor antagonists block development of LTP (Collingridge, 1985). Furthermore, Morris et al. (1986) demonstrated that NMDA antagonists impair spatial discrimination learning and LTP in vivo. In humans, dissoclative anesthetics such as ketamine, which are noncompetitive NMDA antagonists, cause amnesia of the events in the perloperative period. Thus, NMDA receptors appear to be intimately involved In learning and memory function. The profound 1088 of NMDA receptors in cortex and hippocampus of DAT brains may provide an explanation for the learning and memory deficits which are prominent in DAT.

Table 3

The role of glutamate in the symptoms of DAT

- Cortical disconnection: there is pre- and postaynaptic evidence for disruption of glutamatergic association pathways.

- Learning \& memory defictts: NMDA receptors, which are cruclal to learning and memory, are lost in DAT.

- The degree of dementia correlates with the loss of cortical (? glutamate) pyramidal neurons.

- Cognitive test scores correlate with CSF glutamate levels in DAT patients.

\section{In V1vo Imaging}

At present, DAT is a "diagnosis of exclusion." After all other potential causes of dementia are ruled out, the tentative diagnosis of DAT can be made; ultimate confirmation of the diagnosis depends on pathological studies at autopsy. Even after extensive work up, the antemortem diagnosis of DAT is proven incorrect in about 10 to $30 \%$ of cases (Khachaturian, 1985). Th1s is clearly not adequate, since any potential therapy for DAT will only be useful if there is a means of early, accurate diagnosis.

It is possible that the 1038 of glutamate receptors in DAT may be exploited for diagnostic purposes. With the advent of PET scanning, various receptor complexes have been imaged in vivo in humans (Wagner et al., 1983). Perhaps, the NMDA receptor complex can be labeled in vivo In a similar fashion. Although current NMDA receptor $11 g$ ands have Iimited access through the blood-brain barrier, dissociative anesthetics such as ketamine have ready access to the brain. Similar drugs, acting at the NMDA receptor 1on channel, may ultimately prove useful for the early, accurate diagnosis of DAT using PET scanning . 


\section{Therapy}

Because exc1totoxic mechanisms may play a role in the pathogenesis of DAT, treatment with receptor antagonists $\mathrm{might}$ seem attractive at first glance. However, whereas aberrantly enhanced glutamatergic transmission may be a causative factor in DAT, a relative "glutamatergic deficit" may be responsible for the clinical manifestations of the disease. Thus, although glutamate receptor blockers might be expected to halt the progression of the disease, they could have the paradoxical effect of exacerbating memory dysfunction and signs of cortical disconnection. Similarly, an agonist might help the symptoms but accelerate the progression of the disease. Perhaps, development of a partial agonlst would provide therapy for both the symptoms and pathogenesis of the disease.

In this context, it is of interest to examine the apparent success of the cholinesterase inhlbitor, tetrahydroaminoacridine (THA), In amellorating the cognitive deficits of DAT (Summers et al., 1986). Why should this cholinesterase inhibitor be effective when other drugs of this class have been remarkable for their lack of efficacy? THA has a complex pharmacology. In addition to its inhibition of cholinesterase, it reduces the duration of anesthesia caused by dissociative anesthetics and reverses magnesium chloride-induced coma (Shaw and Bentley, 1979; Albin et al., 1974). We recently measured the ability of THA to displace specific binding at dissoclative anesthetic binding sites (Young et a1., 1987). The $\mathrm{IC}_{50}$ of THA at this site was $30 \mathrm{uM}$, roughly simllar to 1 ts $\mathrm{K}_{\mathrm{m}}$ for acetylcholinesterase. Thus, THA is almost as potent at dissociative anesthetic binding sites as at the cholinesterase enzyme. other cholinesterase inhibitors such as physostigmine, edrophonium and neostigmine were much weaker displacers, as were a series of potasslum channel blockers. These results suggest that THA may exert some of its effects at the NMDA receptor complex. The beneficial effects of THA in DAT may be attributable to its simultaneous modulation of both cholinergic and glutamatergic neurotransmission.

\section{Conclusions}

Glutamate is the major excitatory transmitter of the cortex and hippocampus; it is also a neurotoxin. Existing data suggests a role for the glutamatergic system in the pathogenesis, clinical manifestations, diagnosis and treatment of DAT. This article 1s intentionally speculative and it will hopefully stimulate more research in this area. Perhaps its most Important feature is that it provides testable hypotheses.

\section{Acknowledgements}

We thank Darrell Debowey and Zane Hollingsworth for expert technical assistance. Th1s work was supported by the A.C. and Ersa Arbogast Foundation and USPHS Grant NS 15655. 


\section{$\underline{\text { References }}$}

ALBIN, M.S., BUNEGIN, L., MASSOPUST, L.C. and JANETTA, P.J. (1974) Ketamine-1nduced post anesthetic delerium attenuated by tetrahydroaminoacridine. Exp. Neurol. 44: 126129.

COLLINGRIDGE, G.L. (1985) Long term potentiation in the hippocampus: mechanisms of inftiation and modulation by neurotransmitters. Trends Pharmacol. Sc1. 6: 407-411.

COYLE, J.T., PRICE, D.L. and DE LONG, M.A. (1983) Alzheimer's disease: A disorder of cortical cholinergic innervation. Science 219: 1184-1190.

DE BONI, U. and CRAPPER-MC LACHLAN, D.R. (1985) Controlled induction of palred helical filaments of the Alzhelmer type in cultured human neurons, by glutamate and aspartate. J. Neurol. Sci. 68: 105-118.

DEBOWEY, D.L., MARAGOS, W.F., HOLLINGSWORTH, Z., GREENAMYRE, J.T., YOUNG, A.B. and PENNEY, J.B. (1987) Receptor changes in hippocampus of Alzheimer's disease. Soc. Neurosc1. Abstr. 13, In press.

ENGELSEN, B. (1986) Neurotransmitter glutamate: its clinical importance. Acta Neurol. Scand. $\underline{74}$ : 337-355.

FAGG, G.E. and FOSTER, A.C. (1983) Amino acid neurotransmitters and their pathways in the mammalian central nervous system. Neuroscience 9: 701-719.

FOSTER, A.C. and FAGG, G.E. (1984) Acidic amino actd binding sites in mammallan neuronal membranes: Their characteristics and relationship to synaptic receptors. Brain Res. Rev. 7: 103-164.

GEDDES, J.W., CHIU, H.-C., COOPER, S.M., LOTT, I.T. and COTMAN, C.W. (1986) NMDA receptors in Alzheimer's disease. Brain Res. 399: 156-161.

GREENAMYRE, J.T. (1986) The role of glutamate in neurotransmission and in neurologic disease. Arch. Neurol. 43: 1058-1063.

GREENAMYRE, J.T., OLSON, J.M.M., PENNEY, J.B. and YOUNG, A.B. (1985a) Autoradiographic characterization of N-methy1-D-aspartate-, quisqualate- and kainate-sensitive glutamate binding sites. J. Pharmaco1. Exp. Ther. 233: 254-263.

GREENAMYRE, J.T., PENNEY, J.B., D'AMATO, C.J. and YOUNG, A.B. (1987) Dement1a of the Alzheimer's type: Changes in hippocampal $\mathrm{L}-\left[{ }^{3} \mathrm{H}\right] \mathrm{glutamate}$ binding. J. Neurochem. 48 : 543-551.

GREENAMYRE, J.T., PENNEY, J.B., YOUNG, A.B., D'AMATO, C.J., HICKS, S.P. and SHOULSON, I. (1985b) Alterations in L-glutamate binding in Alzhefmer's and Huntington's disease. Science 227: 1496-1499.

GREENAMYRE, J.T., YOUNG, A.B. and PENNEY, J.B. (1984) Quantitative autoradiographic distribution of $\mathrm{L}-\left[{ }^{3} \mathrm{H}\right]$ glutamate binding sites in rat central nervous system. J. Neuosci. 4: 2133-2144.

HALPAIN, S.H., WIECZOREK, C.M. and RAINBOW, T.C. (1984) Localization of L-glutamate receptors in rat brain by quantitative autoradlography. J. Neurosc1. 4: 2247-2258.

HYMAN, B.T., VAN HOESEN, G.W. and DAMASIO, A.R. (1986) Glutamate depletion of the perforant pathway terminal zone in Alzheimer disease. Soc. Neurosc1. Abstr. 12: 944.

HYMAN, B.T., VAN HOESEN, G.W., DAMASIO, A.R. and BARNS, C.L. (1984) Alzheimer's 
disease: ce11-specific pathology isolates the hippocampal formation. Sclence 225: 1168-1170.

KHACHATURIAN, Z.S. (1985) Diagnosis of Alzheimer's disease. Arch Neuro1. 42: 1097-1105.

LORENTE DE NO, R. (1934) Studies on the structure of the cerebral cortex II. Continuation of the study of the ammonic system. J. Psychol. Neurol. 46: 113-177.

LUCAS, D.R. and NEWHOUSE, J.P. (1957) The toxic effect of sodium L-glutamate on the inner layers of the retina. Arch. Ophthalmol. 58: 193-204.

MANN, D.M.A., YATES, P.0. and MARCYNIUK, B. (1986) A comparison of nerve cel1 loss in cortical and subcortical structures in Alzheimer's disease. J. Neurol. Neurosurg. Psychiatry 69: 139-159.

MARAGOS, W.F., CHU, D.C.M., GREENAMYRE, J.T., PENNEY, J.B. and YOUNG, A.B. (1986) H1gh correlation between the localization of $\left[{ }^{3} \mathrm{H}\right] \mathrm{TCP}$ binding and NMDA receptors. Eur. J. Pharmacol. 123: 173-174.

MARAGOS, W.F., CHU, D.C.M., YOUNG, A.B., D'AMATO, C.J. and PENNEY, J.B. (1987) Loss of hippocampal [ $\left.{ }^{3} \mathrm{H}\right] \mathrm{TCP}$ binding in Alzheimer's disease. 14 : 371-376.

MARTIN, D. and LODGE, D. (1985) Ketamine acts as a non-competitive N-methy1-D-aspartate antagonist on frog spinal cord in vitro. Neuropharmacology 24: 999-1003.

MC KINNEY, M., DAVIES, P. and COYLE, J.T. (1982) Somatostatin is not co-localized in cholinergic neurons innervating the rat cerebral cortex - hippocampal formation. Brain Res. 243: 169-172.

MEHRAEIN, P., YAMADA, M. and TARNOWSKA-DZIDUSZKO, E. (1975) Quant1tative study on dendrites and dendritic spines in Alzhelmer's disease and sentle dementia. Adv. Neurol. 12: 453-458.

MESULAM, M.-M., VOLICER, L., MARQUIS, J.K., MUFSON, E.J. and GREEN, R.C. (1986) Systemmatic regional differences in the cholinergic innervation of the primate cerebral cortex: Distribution of enzyme activities and some behavioral implications. Ann. Neurol. 34: 741-751.

MONAGHAN, D.T. and COTMAN, C.W. (1985) Distribution of N-methyl-D-aspartate-sensitive $\mathrm{L}-\left[{ }^{3} \mathrm{H}\right]$ glutamate binding sites in rat brain. J. Neurosci. 5: 2909-2919.

MONAGHAN, D.T., GEDDES, J.W., YAO, D., CHUNG, C. and COTMAN, C.W. (1987) [ $\left.{ }^{3} \mathrm{H}\right] \mathrm{TCP}$ binding sites in Alzhelmer's disease. Neurosci. Lett. 73: 197-200.

MORRIS, R.G.M., ANDERSON, E., LYNCH, G. and BAUDRY, M. (1986) Selective impairment of learning and blockade of learning and blockade of long term potentiation by an $N-$ methy1-D-aspartate receptor antagonist, AP5. Nature $\underline{319: 774-776 .}$

NOWAK, L., BREGESTOVSKI, P., ASCHER, P., HERBERT, A. and PROCHIANTZ, A. (1984) Magnesium gates glutamate-activated channels in mouse central neurons. Nature 307: 460-462.

OLNEY, J.W., FULLER, T. and DE GUBAREFF, T. (1979) Acute dendrotoxic changes in the hippocampus of ka1nate-treated rats. Brain Res. 176: 91-100.

PEARSON, R.C.A., ESIRI, M.M., HIORNS, R.W., WILCOCK, G.K. and POWELL, T.P.S. (1985) Anatomical correlates of the pathological changes in the neocortex in Alzheimer's disease. Proc. Nat1. Acad. Sci. USA 82: 4531-4534.

ROGERS, J. and MORRISON, J.H. (1985) Quantitative morphology and regional laminar 
distributions of senile plaques in Alzheimer's disease. J. Neurosc1. 5: 2801-2808.

SELKOE, D.J. (1987) Deciphering Alzheimer's disease: the pace quickens. Trends Neurosc1. 5: 181-184.

SHAW, F.H. and BENTLEY, G. (1979) Some aspects of the pharmacology of morphine with special reference to its antagonism by 5-aminoacridine (THA) and other chemically related compounds. Hed. J. Aust. $\underline{2}$ : 868-874.

SMITH, C.C.T., BOWEN, D.M., FRANCIS, P.T., SNOWDEN, J.S. and NEARY, D. (1985) Putat1ve am ino acid transmitters in lumbar cerebrospinal fluld of patients with histologically verifled Alzheimer's dementia. J. Neurol. Neurosurg. Psychiatry 48: 469-471.

SOFRONIEW, M.V. and PEARSON, R.C.A. (1985) Degeneration of cholinergic neurons in the basal nucleus following kainic or N-methy1-D-aspartic acid application to the cerebral cortex in the rat. Brain Res. 339: 186-190.

SUMMERS, W.K., MAJOVSKI, L.V., MARSH, G.M., TACHIKI, K. and KLING, A. (1986) Oral tetrahydroaminoacridine in long-term treatment of senile dementia, Alzheimer type. N. Engl. J. Med. 315: 1241-1245.

TERRY, R.D., PECK, A., DE TERESA, R., SCHECHTER, R. and HOROUPIAN, D.S. (1981) Some morphometric aspects of the brain in sentle dementia of the Alzheimer type. Ann. Neuro 1. 10: 1168-1170.

WAGNER, H.N., BURNS, H.D., DANNALS, R.F., WONG, D.F., LANGSTROM, B., DUELFERT, T., FROST, J.J., RAVERT, H.T., LINKS, J.M., ROSENBLOOM, S.B., LUKAS, S.E., KRAMER, A.V. and KUHAR, M.J. (1983) Imaging dopamine receptors in the human brain by positron tomography. Science 221: 1264-1266.

WATKINS, J.C. and EVANS, R.H. (1981) Excltatory amino acid transmitters. Annu. Rev. Pharmacol. Tox1col. 21: 165-204.

WURTMAN, R.J., CORKIN, S.J. and GROWDON, J.H., eds. (1984) Alzhe1mer's Disease: Advances in Bastc Research and Therapies. Center for Brain Sciences and Metabolism Charitable Trust, Cambridge, Massachusetts.

YOUNG, A.B., ALBIN, R.L., ALBIN, M.S., PENNEY, J.B., GREENAMYRE, J.T. and MARAGOS, W.F. (1987) 1,2,3,4-tetrahydro-9-aminoacridine and other acridine derivatives are displacers of specifically bound [ $\left.{ }^{3} \mathrm{H}\right]-\mathrm{N}-(1-[2-t h 1 e n y 1]-c y c 10$ hexyl)-3,4-piperadine. Soc. Neurosc1. Abstr. 13 , In press.

Inquiries and reprint requests should be addressed to:

Dr. J. Timothy Greenanyre

Department of Neurology

University of Michigan

Neuroscience Laboratory Bullding

1103 East Huron St.

Ann Arbor, MI 48104

U.S.A. 